\title{
EFFECT OF VIRGIN COCONUT OIL ON MYCOBACTERIUM SMEGMATIS AND STAPHYLOCOCCUS AUREUS TREATED WITH EXTRACTS OF ZANTHOXYLUM ACANTHOPODIUM FRUIT
}

\author{
HEDDY JULISTIONO*, INTAN PERMATASARI SUSENO, NURUL HANDAYANI, RINI HANDAYANI, \\ PUSPA DEWI LOTULUNG
}

Research Center for Chemistry LIPI, Jakarta, Indonesia. Email: hedd001@lipi.go.id

Received: 11 May 2021, Revised And Accepted: 20 July 2021

\begin{abstract}
Objectives: To understand the potency of herbal formulation of virgin coconut oil (VCO) and andaliman (Zanthoxylum acanthopodium) fruit activity against microbes, effects of ethylene acetate and hexane extracts of fruit of andaliman on viability and ions leakages of Mycobacterium smegmatis dan Staphylococcus aureus treated with VCO has been investigated.
\end{abstract}

Methods: Antibacterial activity of extracts of andaliman fruit, or VCO, or andaliman and VCO against M. smegmatis and S. aureus was investigated using MTT assay method. Membrane disruption of bacterial cells treated with the plant extract and VCO was determined by measuring potassium and sodium ions leakages using Atomic Adsorbtion Spectrophotometer.

Results: VCO of $512 \mu \mathrm{g} / \mathrm{ml}$ did not have antibacterial activity. In M. smegmatis treated with andaliman hexane extract, presence VCO decreased both ions leakage whereas in S. aureus treated with ethyl acetate extract only sodium ion was decreased. In both microorganisms, VCO could not protect cells of both M. smegmatis and S. aureus from death caused by andaliman extracts.

Conclusions: VCO prevented ions leakages of the bacteria treated with extract of andaliman but did not protects cells from death.

Key words: Mycobacterium smegmatis, Staphylococcus aureus, Virgin coconut oil, Zanthoxylum acanthopodium, Ions leakages.

(C) 2021 The Authors. Published by Innovare Academic Sciences Pvt Ltd. This is an open access article under the CC BY license (http://creativecommons.org/ licenses/by/4.0/) DOI: http://dx.doi.org/10.22159/ajpcr.2021v14i8.38219. Journal homepage: https://innovareacademics.in/journals/index.php/ajpcr

\section{INTRODUCTION}

Traditional coconut oil, which is widely known before virgin coconut oil (VCO), is an oil that is processed from dried coconut (Cocos nucifera) called as copra. However, nowadays, the VCO, refined coconut oil, has been becoming more popular due to its unchanging oil content and vitamins content such as provitamin A, Vitamin E, phytosterol, and polyphenol. VCO is also free of aflatoxin and not rancid. The concept of VCO production was inspired by virgin olive oil (VOO). Virgin oil is produced from olive oil in the Mediterranean region [1]. VCO is processed from fresh and ripe coconut flesh mechanically or naturally (without heat), by chemical distillation, bleaching process, and deodorization to maintain oil content [2]. Some examples of VCO health benefits were immunomodulators in chickens [3] and antibacteria used directly $[4,5]$ and through pretreatment to release bound fatty acid content [6]. VOO could be enriched with herbal mixture that has certain ability such as antioxidants to obtain health product that can be used both orally and topically [7]. One of the advantages of this method is the application of herbal maceration via "green process" in oil.

In the effort of discovering the potential of VCO to be used with medicinal plants in a combined-formula, a preliminary study of the toxicity of the mixture of VCO and fruit extract of Andaliman (Zanthoxylum acanthopodium) on Mycobacterium smegmatis and Staphylococcus aureus was carried out. The andaliman fruit essential oil is notorious to have anti-bacterial [8] and anti-mycobacterial activities [9]. M. smegmatis is a type of a non-virulent Mycobacterium genus that was used as a model to study pathogenic Mycobacterium responses including Mycobacterium tuberculosis [10-12]

According to Yoon et al. [13], the cell membrane of bacteria is one of the targets of fatty acids, as well as essential oils, antibacterial action [14] that resulted in the cell membrane damage. Therefore, in this research, the study of VCO and fruit andaliman effects on Gram-positive bacteria $M$. smegmatis and $S$. aureus was emphasized on the destruction of membranes characterized by the leaking of $\mathrm{K}+$ dan $\mathrm{Na}+$ ions.

\section{METHODS}

Bacterial and mycobacterial cultures

The cultures of $S$. aureus InaCC-B4 and M. smegmatis NBRC 3082 were obtained from INACC LIPI, Indonesia. Laboratory collection of Lactobacillus plantarum was used for coconut oil fermentation.

Plant extract

The plants and green andaliman fruits were obtained from North Sumatra about $24 \mathrm{~h}$ after the harvest. Plants were identified in Herbarium Bogoriense, Indonesia. Before the extraction, andaliman fruits were stored at $4^{\circ} \mathrm{C}$ overnight. As many as, $366 \mathrm{~g}$ of fruits was extracted with $1500 \mathrm{ml}$ of hexane; and then the residue was extracted with ethyl acetate.

Coconut milk was fermented by L. plantarum for $24 \mathrm{~h}$ for VCO preparation. The oil formed was separated from the water, and then filtered with filter paper [4]. Fatty acids content of this VCO is presented in Table 1.

\section{The growth of target microbes}

The cultures of $M$. smegmatis and $S$. aureus InaCC-B4 were grown on $100 \mathrm{ml}$ of liquid media (Nutrient Broth, NB, HIMEDIA) in $300 \mathrm{ml}$ Erlenmeyer flask, incubated on a shaker at $100 \mathrm{rpm}$ and room temperature for $72 \mathrm{~h}$ (M. smegmatis) and $24 \mathrm{~h}$ (S. aureus).

Minimum inhibition concentration (MIC) measurement Anti-mycobacterial or antibacterial activity was measured as MIC using MTT (Thiazolyl Blue Tetrazolium Blue) according to. ${ }^{[15-17]}$ MIC 
determination was performed on "microplate" with 96 wells at room temperature. The measurement of hexane extract on $M$. smegmatis was done by inoculating the culture (final concentration was $1 \% \mathrm{v} / \mathrm{v}$ ) with as much as $100 \mu \mathrm{l}$ (with one series of extract concentration on media ranging from $521 \mu \mathrm{g} / \mathrm{ml}$ and $1 \%(\mathrm{v} / \mathrm{v})$ Tween 80$)$ on NB media. It was then diluted twice and continued until the final concentration of $1 \mu \mathrm{g} /$ $\mathrm{ml}$, shaken at $100 \mathrm{rpm}$ for $72 \mathrm{~h}$. The initial concentration of $S$. aureus started on the concentration after 24-h incubation. After incubation, as much as $10 \mu \mathrm{l}$ of MTT solution ( $5 \mathrm{mg} / \mathrm{ml}$ ) was added to each suspensions and the suspension was incubated for $2 \mathrm{~h}$. After incubation, a total of 11 $\mu \mathrm{l}$ of propanol containing $0,04 \mathrm{M} \mathrm{HCl}$ was added to the cell suspension and it was incubated for $2 \mathrm{~h}$. The reduction of MTT by the cell enzymes produced fomazan. It then was measured using a microplate reader at the wavelength of $595 \mathrm{~nm}$. MIC was determined at the same absorbance of the NB media, the absorbance at the time of reduction of MTT into formazan since there was no activity of the reducing enzyme detected. As the positive control, M. smegmatis culture was added with $8 \mu \mathrm{g} / \mathrm{ml}$ of rifampicin while $S$. aureus was added with $32 \mu \mathrm{g} / \mathrm{ml}$ of amoxicillin.

The effect of the mixture of VCO and andaliman fruits extract on the viability of M. smegmatis or S. aureus

Principally, the method of studying the effect of VCO and fruit extract of andaliman on microbes viability was carried out as in MIC measurement. The treatments included; the effect of $512 \mu \mathrm{g} / \mathrm{ml}$ of VCO on both tested microbes, the mixture of $512 \mu \mathrm{g} / \mathrm{ml} \mathrm{VCO}$ and $64 \mu \mathrm{g} / \mathrm{ml}$ of hexane extract of andaliman fruit on M. smegmatis or $2048 \mu \mathrm{g} / \mathrm{ml}$ of ethyl acetate extract on $S$. aureus.

\section{Measurements of cell leakage}

The effects of VCO and andaliman extracts on the damage of cell membrane were observed indirectly by inspecting the ion leakage on cell membrane [18]. About $2 \times 100 \mathrm{ml}$ of 1 day old $S$. aureus culture and 3 days old of $M$. smegmatis culture were harvested through centrifugation at $15.000 \mathrm{~g}$ for $10 \mathrm{~min}$. The pellets were washed with sterile distillation water and centrifuged. Sterile physiology solution was added into the pellet until the volume was $10 \mathrm{ml}$. About $1 \mathrm{ml}$ of the suspension was taken for $512 \mu \mathrm{g} / \mathrm{ml} \mathrm{VCO}$ treatment, $64 \mu \mathrm{g} / \mathrm{ml}$ of the hexane extract of the fruit andaliman (M. smegmatis) treatment or $2048 \mu \mathrm{g} / \mathrm{ml}$ of ethyl acetate extract ( $S$. aureus) treatment, mixed VCO $512 \mu \mathrm{g} / \mathrm{ml}$ and $64 \mu \mathrm{g} / \mathrm{ml}$ of hexane extract of andaliman fruit (M. smegmatis) treatment, mixture of $512 \mu \mathrm{g} / \mathrm{ml} \mathrm{VCO}$ and $2048 \mu \mathrm{g} / \mathrm{ml}$ of ethyl acetate extract (S. aureus) treatment and without treatment (control). The culture was incubated at room temperature on a shaker at $100 \mathrm{rpm}$. The supernatant of $S$. aureus was taken after one day incubation by centrifugation and 3 days incubation for (M. smegmatis). The amount of $\mathrm{K}+$ and $\mathrm{Na}+$ ions in the supernantan were measured using Atomic (Atomic Adsorbtion Spectrophotometer, Shimadzu AA - 6800).

\section{RESULTS AND DISCUSSION}

MIC of andaliman fruit extract and VCO on M. smegmatis or S. aureus As shown in Table 1, the MIC of VCO was undetected up to the concentration of $512 \mu \mathrm{g} / \mathrm{ml}$. This result corresponded to the absence of the inhibition area on a paper disc with $100 \%$ VCO (data was not shown). Table 1 shows that the andaliman fruit extracts antimicrobial activity depended on the target microbial. M. smegmatis was more

Table 1: The fatty acids composition of VCO sample analyzed using gas chromatography

\begin{tabular}{ll}
\hline Fatty Acids & Percentage \\
\hline Caprylic acid & 9.028 \\
Capric acid & 6.825 \\
Lauric acid & 41.693 \\
Myristic acid & 17.121 \\
Palmitic acid & 9.092 \\
Oleic acid & 11.148 \\
Linoleic acid & 3.839 \\
Linolenic Acid & Not detected \\
\hline VCO: Virgin
\end{tabular}

susceptible to hexane extract of andaliman fruits; while $S$. aureus was vulnerable to ethyl acetate extract. The MICs of hexane and ethyl acetate extracts against $M$. smegmatis and $S$. aureus were $64 \mu \mathrm{g} / \mathrm{ml}$ and $2408 \mu \mathrm{g} / \mathrm{ml}$ respectively. Hexane extract of $64 \mu \mathrm{g} / \mathrm{ml}$ and ethyl acetate extracts of $2408 \mu \mathrm{g} / \mathrm{ml}$ was then applied to investigate the effect of VCO and andaliman fruit extracts on the viability and ions leakage on M. smegmatis and S. aureus.

The effect of the mixture of VCO and andaliman fruit extracts on the viability of $M$. smegmatis or S. aureus

Fig. 1a shows that VCO did not have antimicrobial activity of $M$. smegmatis, whereas andaliman hexane extract of $64 \mu \mathrm{g} / \mathrm{ml}$ caused cell death. The mixture of VCO and fruit andaliman extract treatment also resulted in cell death. This phenomenon implied that the VCO did not possess protective properties against the toxicity of andaliman fruit extract.

Fig. 1b also shows that the effect of the mixture of VCO and andaliman fruit extract on the viability of $S$. aureus showed the same pattern as the effect on mycobacteria.

The effect of the mixture of VCO and andaliman fruit extract on the ion leakage

Bacterial cell membrane or cytoplasm could be a target for antibacterial action of essential oil [14]. Ion leakage on target mycobacteria and bacteria treated with VCO and andaliman fruit extract was observed to obtain initial description of membrane as the target of the VCO and fruit extract of andaliman. However, the release of ions from the cytoplasm was not solely a result of membrane destruction but it might be caused by the changes in "ion channel" activity without any membrane damage [19].

In M. smegmatis, hexane extract of andaliman caused the increase of $\mathrm{K}+$ and $\mathrm{Na}+$ ions in supernatant however VCO decreased the ions content (Fig. 2a and b). Data presented in Fig. 2a and b demonstrate that VCO was able to attenuate ions leakage induced by andaliman extract.

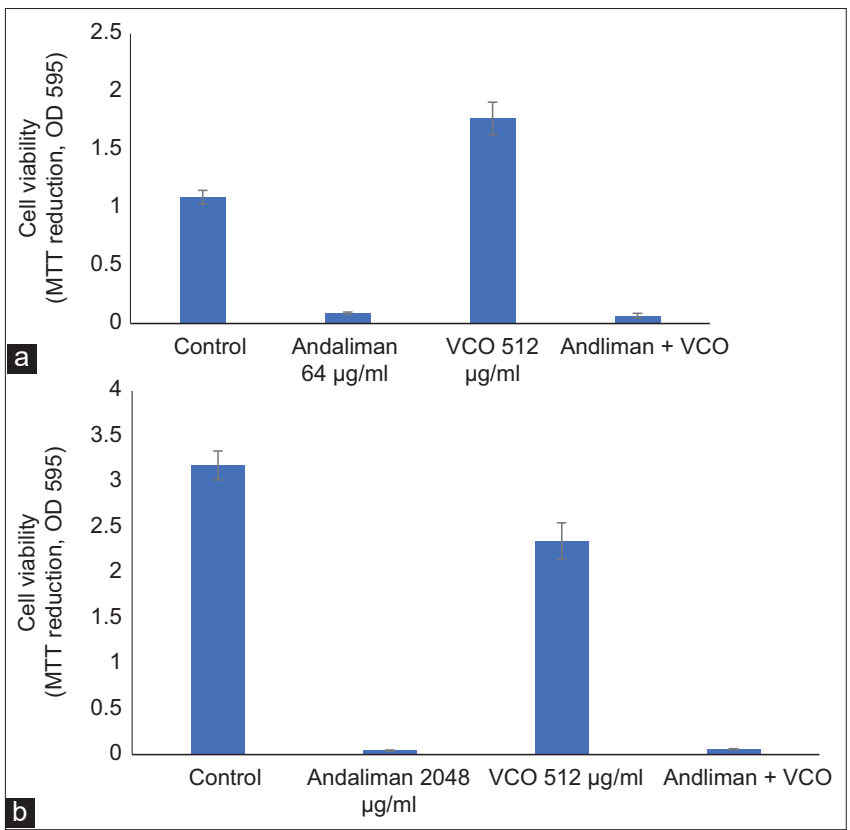

Fig. 1: (a) Effect of hexane extract of andaliman fruit and Virgin coconut oil on viability of Mycobacterium smegmatis. Bars represent mean \pm standard error of three independent experiments. (b) Effect of ethyl acetate extract of andaliman fruit and virgin coconut oil on viability of Staphylococcus aureus. Bars represent mean \pm standard error of three independent experiments 


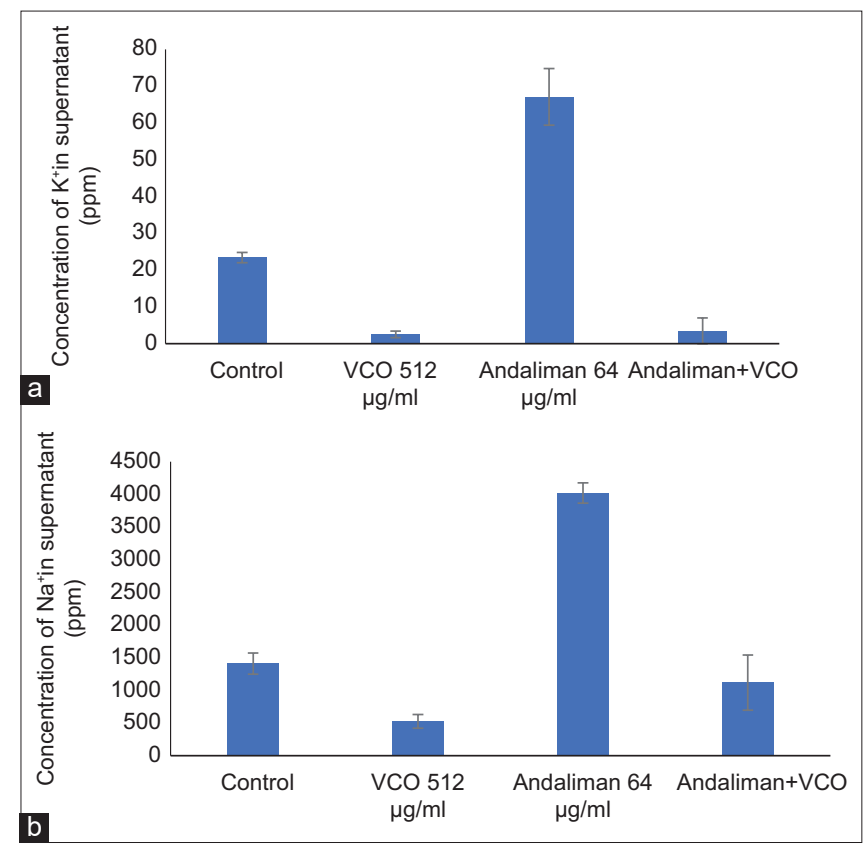

Fig. 2: (a) Effect of hexane extract of andaliman fruit and virgin coconut oil on $\mathrm{K}^{+}$ion leakage in Mycobacterium smegmatis. Bars represent mean \pm standard error of three independent experiments. (b) Effect of hexane extract of andaliman fruit and virgin coconut oil on $\mathrm{Na}+$ ion leakage in Mycobacterium smegmatis. Bars represent mean \pm standard error of three independent experiments

In $S$. aureus treated with andaliman extract, the increase of both $\mathrm{K}+$ and $\mathrm{Na}+$ ions was also observed but VCO had no effect on ions leakage (Fig. 3a and b). Although VCO has no effect on the movement of ions across cell membrane, it could attenuate $\mathrm{Na}+$ leakage in cells treated with andaliman extract (Fig. 3b) not K+ (Fig. 3a). Therefore, compared to M. smegmatis, S. aureus responded differently to VCO.

\section{DISCUSSION}

Our results show that VCO had no inhibitory capability to $M$. smegmatis or S. aureus Loung et al. [6]. reported that the VCO was not active against S. aureus, Salmonella typhi, and Escherichia coli. However, free lauric acid showed antibacterial activity toward those microbes. Although VCO contained lauric acid (Table 2), it did not have antibacterial activity unless the lauric acid was released from the glycerol of VCO. In S. aureus, Chen and Alonzo [20] demonstrated a secreted lipase of $S$. aureus that could inactivate bacterial-derived lipoproteins and change the local inflammatory environment [17]. Lipolytic enzymes of the bacteria that could be able to release free lauric acid from VCO could, therefore, harmful for bacteria itself.

The essential oils contained in the fruit of andaliman that possess antibacterial activity were reported by [8]. Our previous research showed that geranyl acetate of andaliman extract was responsible for cell death in M. smegmatis exerting ion leakage [9]. The presence of andaliman fruit hexane extract resulted in the leakage of $\mathrm{K}^{+}$ions and $\mathrm{Na}^{+}$while the presence of VCO attenuated this harmful effect of the extract (Fig. 2a and b). This data indicated that toxicity of andaliman extract in M. smegmatis involved not only the cell wall or membrane but also its effect on the cytoplasm as described by Nazzaro et al. [14]. Interestingly, in M. smegmatis VCO decreased potassium and kalium ions in supernatant whereas cell viability was not affected. Note that VCO is emulsified by Tween 80 . Mechanism by which VCO inhibits ions movement out of the cells is not known. However, it is known that lipids in cell membrane could affect ion channel activity [21,22].

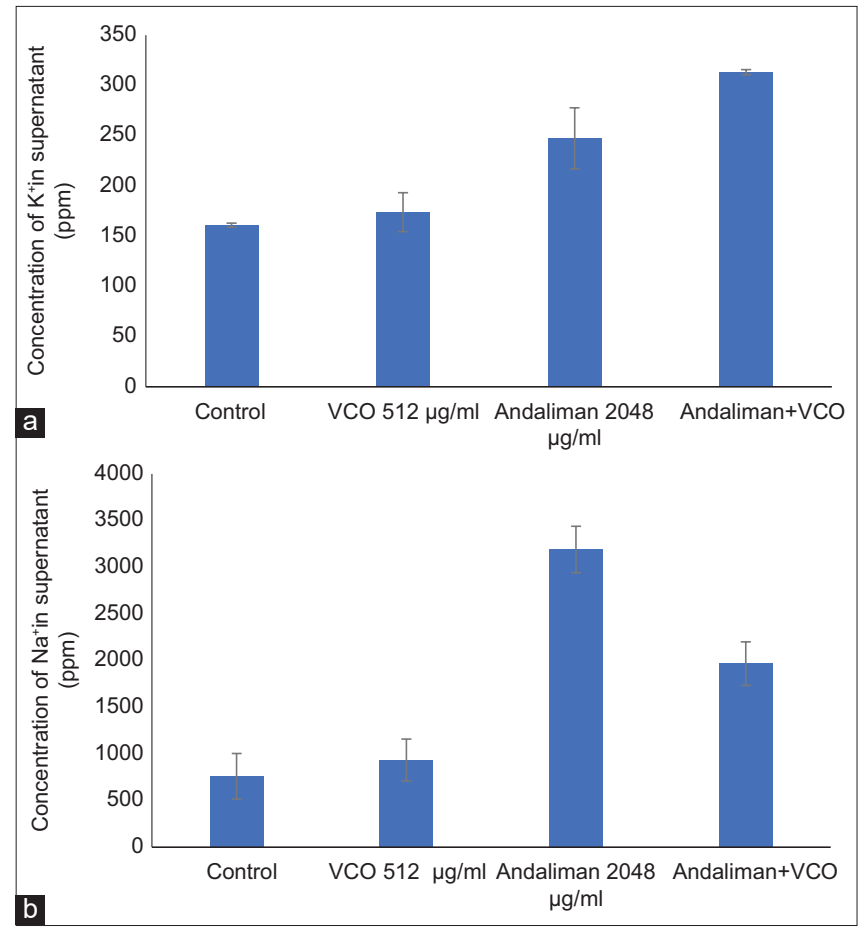

Fig. 3: (a) Effect of ethyl acetate extract of andaliman fruit and virgin coconut oil on $\mathrm{K}^{+}$ion leakage in Staphylococcus aureus. Bars represent mean \pm standard error of three independent experiments. (b) Effect of ethyl acetate extract of andaliman fruit and virgin coconut oil on $\mathrm{Na}^{+}$ion leakage in Staphylococcus aureus. Bars represent mean \pm standard error of three independent experiments

Table 2: MIC of VCO and extracts of andaliman fruit on M. smegmatis and S. aureus

\begin{tabular}{|c|c|c|c|}
\hline \multirow{2}{*}{$\begin{array}{l}\text { Target } \\
\text { microbe }\end{array}$} & \multicolumn{2}{|c|}{ MIC of andaliman extracts $(\mu \mathrm{g} / \mathrm{ml})$} & \multirow{2}{*}{$\begin{array}{l}\text { MIC of VCO } \\
(\mu \mathrm{g} / \mathrm{ml})\end{array}$} \\
\hline & hexane & Ethyl acetate & \\
\hline $\begin{array}{l}\text { M. smegmatis } \\
\text { S. aureus }\end{array}$ & $\begin{array}{l}64 \\
>2408\end{array}$ & $\begin{array}{l}>2408 \\
2408\end{array}$ & $\begin{array}{l}>512 \\
>512\end{array}$ \\
\hline
\end{tabular}

MIC: Minimum inhibition concentration, VCO: Virgin coconut oil.

Since VCO was not toxic (Fig. 2) and did not induce leakage, the presence of VCO was suspected to affect ion exchange activity. To the best of author knowledge, the effect of VCO on mycobacterial membrane and cell wall is still unclear. According to Chen and Alonzo [17], the olive oil interacted with the cell wall of Mycobacterium brumae and affected the cell physiology. Although this study did not have the data on the membrane characters dynamics or the changes on M. smegmatis cell walls treated with $\mathrm{VCO}$, the effect on the cell wall may turn out to be similar to that in M. brumae. Further study on the role of cell wall or membrane on the effects of VCO affecting ionic exchange on M. smegmatis was required.

Contrary to M. smegmatis, the exchange of $\mathrm{K}^{+}$dan $\mathrm{Na}^{+}$ions in S. aureus was not affected by VCO (Fig. 3a and b). The ethyl acetate extract of andaliman resulted in ions leakage and the death of $S$. aureus cells (Fig. 2). VCO was not able to restore the intracellular and extracellular ion balance.

\section{CONCLUSIONS}

VCO had no antibacterial activity but affected the balance of intracellular and extracellular ions in cells of $M$. smegmatis. The extract of the 
andaliman fruits resulted in the leakage of $\mathrm{K}+$ dan $\mathrm{Na}+$ ions and the death of both M. smegmatis and S. aureus. VCO attenuated ions leakage in cells treated with fruit andaliman extract but could not prevent cells death.

\section{ACKNOWLEDGMENT}

This research was supported by Project DIPA LIPI No. 3400.010.002.052 "Utilization of Bioresources in the Food Sector".

\section{CONFLICT OF INTEREST STATEMENT}

The authors had no conflict of interest regarding this manuscript.

\section{AUTHOR CONTRIBUTION STATEMENTS}

HJ: Conceived and planned the experiments, and wrote the manuscript; $\mathrm{NH}$ and IPS performed anti-microorganisms experiments; $\mathrm{RH}$ wrote manuscript and prepared VCO; DPL performed chemical analysis.

\section{REFERENCES}

1. Chua LS, Alitabarimansor M, Lee CT, Mat R. Hydrolysis of virgin coconut oil using immobilized lipase in a batch reactor. Enzyme Res 2012;2012:542589.

2. Bureau of Agriculture and Fisheries Standards, Philippine vco standard, Philipp Natl Stand; 2007. p. 8.

3. Wachidah EY, Asmara W, Artama WT, Tabbu CR. Virgin coconut oil meningkatkan aktivitas fagositosis makrofag ayam pedaging pascavaksinasi flu burung. J Vet 2013;14:190-6.

4. Rini H, Sulistyo J, Rahayu RD. Extraction of coconut oil (Cocos nucifera $\mathrm{L}$.) through fermentation system. Biodiversitas J Biol Divers 2009;10:151-7.

5. Rahmadi A, Abdiah I, Sukarno MD, Purnaningsih T. Karakteristik fisikokimia dan antibakteri virgin coconut oil hasil fermentasi bakteri asam laktat. J Teknol Ind Pangan 2013;24:178-83.

6. Loung FS, Silalahi J, Suryanto D. Antibacterial activity of enzymatic hydrolyzed of virgin coconut oil and palm kernel oil against Staphylococcus aureus, Salmonella thypi and Escherichia coli. Int J Pharmtech Res 2014;6:628-33.

7. Peñalvo GC, Robledo VR, Callado CS, Santander-Ortega MJ, CastroVázquez L, Victoria Lozano $\mathrm{M}$, et al. Improving green enrichment of virgin olive oil by oregano. Effects on antioxidants. Food Chem 2016;197:509-15.

8. Parhusip AJ, Yasni S, Elizabeth Y. Kajian mekanisme antibakteri ekstrak
Andaliman (Zanthoxylum acanthopodium DC) terhadap mikroba patogen dan perusak pangan. J Ilmu Tekno Pangan 2003;1:112-23.

9. Julistiono H, Lestari FG, Iryanto R, Lotulung PD. Antimycobacterial activity of fruit of Zanthoxylum acanthopodium DC against Mycobacterium smegmatis. Avicenna J Phytomed 2018;8:432-8.

10. Campen RL, Ackerley DF, Cook GM, O'Toole RF. Development of a Mycobacterium smegmatis transposon mutant array for characterising the mechanism of action of tuberculosis drugs: Findings with isoniazid and its structural analogues. Tuberculosis 2015;95:432-9.

11. Staudinger T, Redl B, Glasgow BJ. Antibacterial activity of rifamycins for $M$. smegmatis with comparison of oxidation and binding to tear lipocalin. Biochim Biophys Acta 2014;1844:750-8.

12. Fan S, Li DF, Wang DC, Fleming J, Zhang H, Zhou Y, et al. Structure and function of Mycobacterium smegmatis 7-keto-8-aminopelargonic acid (KAPA) synthase. Int J Biochem Cell Biol 2015;58:71-80.

13. Yoon BK, Jackman JA, Kim MC, Cho NJ. Spectrum of membrane morphological responses to antibacterial fatty acids and related surfactants. Langmuir 2015;31:10223-32.

14. Nazzaro F, Fratianni F, De Martino L, Coppola R, de Feo V. Effect of essential oils on pathogenic bacteria. Pharmaceuticals 2013;6:1451-74.

15. Moodley S, Koorbanally NA, Moodley T, Ramjugernath D, and Pillay M. The 3- (4,5-dimethylthiazol-2-yl)-2,5-diphenyl tetrazolium bromide (MTT) assay is a rapid, cheap, screening test for the in vitro antituberculous activity of chalcones. J. Microbiol Methods 2014;104: $72-8$.

16. El Baz AF and Shetaia YM. Evaluation of Different Assays for the Activity of Yeast Killer Toxin. Int J Agr Biol 2005;7:1003-6.

17. Julistiono H, Lestari FG, Iryanto R, Lotulung PD. Antimycobacterial activity of fruit of Zanthoxylum acanthopodium DC against Mycobacterium smegmatis. Avicenna J Phytomed 2018;8:432-8.

18. Suriyanarayanan B, Shanmugam K, Santhosh RS. Synthetic quercetin inhibits mycobacterial growth possibly by interacting with DNA gyrase. Rom Biotechnol Lett 2013;18:8587-93.

19. Demidchik V, Straltsova D, Medvedev SS, Pozhvanov GA, Sokolik A, Yurin V. Stress-induced electrolyte leakage: The role of $\mathrm{K}+$-permeable channels and involvement in programmed cell death and metabolic adjustment. J Exp Bot 2014;65:1259-70.

20. Chen X, Alonzo F. Bacterial lipolysis of immune-activating ligands promotes evasion of innate defenses. Proc Natl Acad Sci USA 2019;116:3764-73

21. Sobko AA, Kotova EA, Antonenko YN, Zakharov SD, Cramer WA. Lipid dependence of the channel properties of a colicin E1-lipid toroidal pore. J Biol Chem 2006;281:14408-16.

22. Weinrich M, Worcester DL, Bezrukov SM. Lipid nanodomains change ion channel function. Nanoscale 2017;9:13291-7. 